\title{
ANALYSIS ON THE SELF-CONFIDENCE PERCEPTIONS OF UNIVERSITY STUDENTS PLAYING TENNIS IN SPORTS ${ }^{1}$
}

\section{TENIS SPORU İLE UĞRAŞAN ÜNIVERSITE ÖĞRENCILERINIIN SPORDA ÖZ-GÜVEN ALGILARININ İNCELENMESİ}

\author{
T. Osman MUTLU ${ }^{1}$, Yavuz ÖNTÜRK ${ }^{2}$, A. Yavuz KARAFIL ${ }^{3}$, Ercan ZORBA ${ }^{1}$, \\ Erkan BINGÖ̈L ${ }^{1}$, Kazım KAYA \\ ${ }^{1}$ Muğla Sitkı Koçman University Faculty of Sports Sciences Muğla / Turkey \\ ${ }^{2}$ Düzce University School of Physical Education and Sports Düzce / Turkey \\ ${ }^{3}$ Mehmet Akif Ersoy University School of Physical Education and Sports Burdur / Turkey \\ ${ }^{4}$ Ahi Evran University School of Physical Education and Sports Kırşehir / Turkey
}

Öz: Bu çalışmada öğrenci sporcuların sporda öz-güven algılarııın bazı değişkenler açısından incelenmesi amaçlanmııştr. Araş̧ırmaya tenis branşı ile uğraşan 41 bayan, 42 erkek olmak üzere toplam 83 sporcu gönüllü olarak katılımıştır. Katılımcıların yaş ortalaması 21,3765 olup Standart sapması 1,60339'dur. Sporcuların öz-güven algılarııı belirlenmesi için Akın'(2007) tarafindan geliștirilen "Sporda Öz-Güven Ölçeği” kullanılmıştır. Kullanılan ölçek beş basamaklı Likert ("1" Hiçbir zaman, "2" Nadiren, "3" Bazen, "4" Genellikle, "5" Her zaman) bir dereceleme ölçeği şeklindedir. Ölçeğin gerekli geçerlilik ve güvenilirlik analizleri yapıııııștır. Verilerin analizinde SPSS 18.0 paket programından yararlanılmıștır. Betimleyici bilgiler için yüzde, frekans, ortalama, standart sapma değerleri, farklı grupların karşılaştırılmasında bağımsız $\mathrm{t}$ testi, çoklu grupların karşılaştırılmasında ise tek yönlü varyans analizi (ANOVA) ve fark oluștuğu durumlarda Tukey HSD posthoc testi uygulanmıştır. Ayrıca değişkenler arasındaki ilişkinin belirlenmesi için korelasyon analizi uygulanmıștır. Anlam düzeyi $\mathrm{p}>0.05$ ve güven aralığı 0.95 kabul edilmiştir parametrik olmayan yani homojen dağılmayan gruplar için ise Kruskal Wallis testi uygulanmış̧ır. Sonuç olarak; Araștırmaya katılan sporcuların öz güven algılarının ceșitli değişkenler açısından inceleniş değişkenler ve öz güven dalgı düzeyleri ile öz güven algılarına ilişkin alt boyutları arasında anlamlı farklılıklara rastlanmamıștır. Cinsiyet değiskeni ve özgüven algısının alt boyutları arasında ki ilişkiye bakıldığında $\mathrm{P}>0,05$ düzeyinde anlamlı farklılı̆ga rastlanmıştır. Ayrıca tenis sporu ile uğraşan sporcuların öz güven puan ortalamalarına göre genel öz güven puan ortalamaları ile alt boyutlar açısından değerlendirildiğinde katılımcıların öz güven puan ortalamalarr; cinsiyet, sportif başarı önemi, bölüm, snnıf, spor yapma süresi ve yaş değişkenlerine göre incelendiğinde yüksek özgüven puan ortalamalarına sahip oldukları görülmüştür.

Anahtar Kelimeler: Spor, Tenis, Özgüven
Abstract: The purpose of this study is to analyze the self-confidence perceptions of athlete-students in sports in terms of some variables. A total of 83 athletes composed of 41 females and 42 males playing tennis voluntarily participated in the research. Average age of the participants is 21,3765 and the standard deviation is 1,60339 . In order to determine the self-confidence perceptions of athletes, "Self-Confidence Scale in Sports" developed by Akın'(2007) was used. The scale used is a fivestep Likert scale (“1" Never, "2" Rarely, "3" Sometimes, "4" Generally, "5" Always). Required validity and reliability analyses of the scale were performed. SPSS 18.0 package program was used in the analysis of data. It was applied percentage, frequency, average and standard deviation values for descriptive statistics; independent $t$ test for the comparison of different groups, one-way variance analysis (ANOVA) for the comparison of multiple groups and Tukey HSD post-hoc test for the occurrence of differences. Besides, correlation analysis was applied to determine the relation between the variables. Significance level was found to be $p>0.05$ and 0.95 was specified as confidence interval. Kruskal Wallis test was implemented for the nonhomogenously -nonparametricly- distributed groups. In conclusion, self-confidence perceptions of participant athletes were analyzed in terms of differen variables, significant differences were not observed between the variables, levels of self-confidence perception and sub-dimensions regarding self-confidence perception. A significant difference of $\mathrm{P}>0,05$ was observed in the relation between the sex variable and the sub-dimensions of self-confidence perception. Moreover, when the general self-confidence and sub-dimensions of athletes are analyzed by demographic variables, it can be stated that general self-confidence averages of athletes are high.

Key Words: Sports, Tennis, Self Confidence

Doi: 10.17363/SSTB.20161816489

(1) Corresponding Author: Yavuz ÖNTÜRK, Duzce University, School of Physical Education and Sports Düzce / Turkey yavuzonturk@hotmail.com Received: 23.12.2015 Accepted: 16.03.2016 Type ofarticle (Research -Application) Conflict of Interest: None / "None of Ethics Committee" 


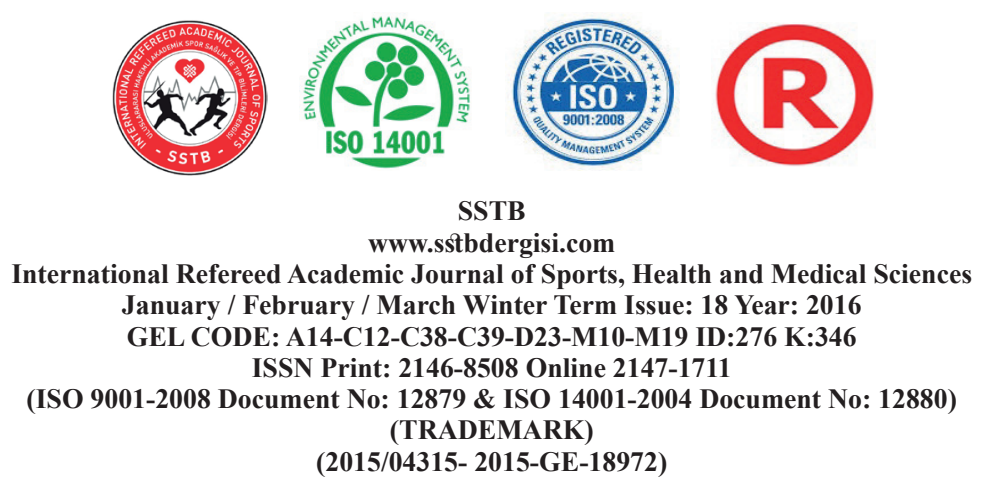

\section{INTRODUCTION}

People are always engaged in behaviors in a social environment. One of their most important features is that they are on the move constantly. These behaviors are observed in their social relations, subsistence efforts and activities of fun and relaxation. Every behavior has a certain goal. These goals can be expressed as the ability to subsist in a balance and harmony (Doğan, 2005). As the sports being a social phenomenon is a well-rounded concept, various scientists have put forth different definitions and expressions regarding the definition of sports. The reason is that the scope, branches, purposes, contents of sports and the ways of doing sports are perceived in different ways (Dalkılıç, 2011).

Although different notions are used in the definitions, the commonly accepted definitions specify that sports is a winning-oriented, technical and physical effort for athletes, an aesthetic process based on competition, a mirror reflecting the social characteristics and lastly a social phenomenon for audiences (Fişek, 1998).

Regarding the concept of self-confidence, there are many definitions for self-confidence in the literature. It can be stated that self-confidence that has become a research topic in recent years in many fields is effective in individuals' daily life, business and family life.
Self-confidence can be expressed as the belief of the individual in herself/himself or believing in the capability to do a task or action. In line with the findings obtained in some researches, it is observed that some people confuse the concept of self-confidence with self-sufficiency.

According to Bandura and Adams (1977), the reason is that the concepts of self-confidence and self-sufficiency are different but similar in conceptual meaning, self-confidence can be specific to a field or general; however, selfsufficiency is only specific to a field.

Researchers have always been interested in determining success acquired in sports, attributing a meaning to this success and analyzing the factors for reaching accomplishment. It is stated that the main factor affecting performance directly which is accepted as the most important element of success in sports is self-confidence (Vealey, Hayashi, GarnerHolman and Giacobbi 1998). The statements playing for winning and playing for not losing are frequently used in sports. Actually, these statements can be defined as the athletes who are confident of themselves and of winning and who are not confident of winning and do not trust themselves due to the fact that they are not aware of their potential performance. However, those who are aware of their skills and performances and believe that they can achieve are self-confident athletes. There is 


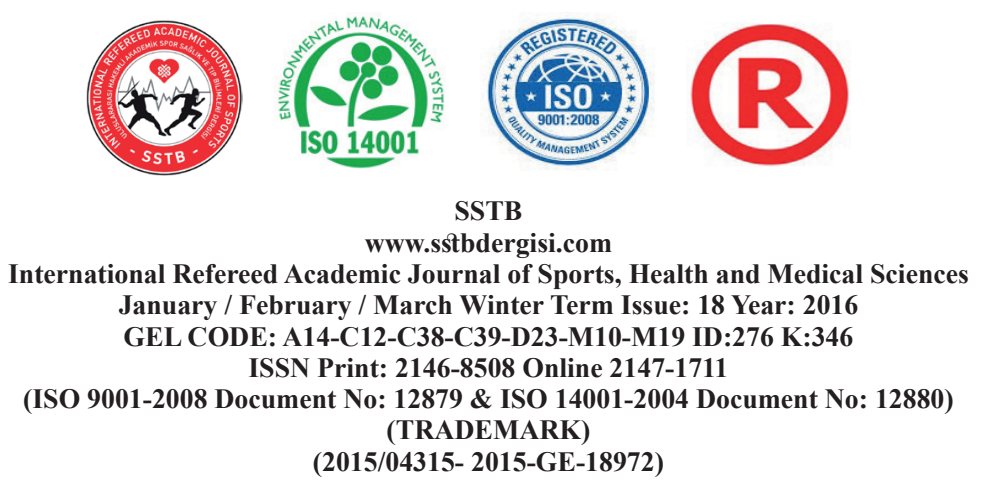

an optimal self-confidence level for every athlete that will enable them to reach their potential performance even though it is not known yet how much that level is for which athlete. Possessing so little self-confidence poses an important problem as much as possessing so much self-confidence. The athlete should know and control this level, see the inadequacies in herself/himself and take the necessary precautions (Yeltepe, 2007). In addition, athletes should also improve their competence skills for all sub-components regarding their performances except from the general high confidence (Konter, 1998).

Confidence in sports can be stated as athlete's level of self-confidence and belief in maintaining the physical skills required for highlevel performance. Furthermore, it is specified that self-confidence in sports is dependent not only on the confidence of athletes in their physical skills and showing high-level performance, but also their belief and confidence in mental competence abilities and the ability to use these skills efficiently and effectively as well as their belief and confidence in physical abilities. The definition of selfconfidence in sports can be stated as; physical skills and level of confidence and belief in these skills and use of mental skills and abilities efficiently, effectively and sustainably (Vealey, 1986).
Vealey (1986) who has conducted many researches regarding self-confidence in sports states that self-confidence in sports is composed of three components. According to Vealey (1986), self-confidence components in sports are;

Self-Confidence and Trait (SC-Trait): In general terms, this trait can be explained as the confidence of an individual in her/his mental and physical skills and how much she/he is sure of herself/himself.

Self-Confidence and State (SC- State): This component is related to how the athlete is feeling that situation. However, this state is temporary.

Competitive Orientation: This component can be explained as athlete's defining success and effective use of mental and physical skills and abilities for success (Vealey, 1986).

Self-confidence in sports which is one of the important topics of sport psychology is known as a factor having direct effect especially on the performances of athletes. It can be said that self-confidence which has effect on such results is highly related and parallel with success in sports.

\section{METHOD}

A total of 83 athletes composed of 41 females and 42 males playing tennis participated in the research voluntarily. Average age of the 


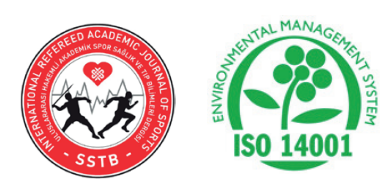

SSTB

www.sstbdergisi.com

International Refereed Academic Journal of Sports, Health and Medical Sciences

January / February / March Winter Term Issue: 18 Year: 2016

GEL CODE: A14-C12-C38-C39-D23-M10-M19 ID:276 K:346

ISSN Print: 2146-8508 Online 2147-1711

(ISO 9001-2008 Document No: 12879 \& ISO 14001-2004 Document No: 12880)

(TRADEMARK)

(2015/04315- 2015-GE-18972)

participants is 21,3765 and the standard deviation is 1,60339 .

It was benefitted from SPSS 18.0 packet program in the analysis of data. It was applied percentage, frequency, average and standard deviation values for descriptive statistics; independent $t$ test for the comparison of different groups, one-way variance analysis (ANOVA) for the comparison of multiple groups and Tukey HSD post-hoc test for the occurrence of differences. Besides, correlation analysis was applied to determine the relation among the variables. Significance level was found to be $p<0.05$ and 0.95 was specified as confidence interval. Kruskal Wallis test was implemented for the nonhomogeneous; that is nonparametric distributed groups.

\section{Data Collection Tools}

In order to determine the self-confidence perceptions of athletes, "Self-Confidence Scale in Sports" developed by Akın (2007) was used. The scale used is a five-step Likert scale ("1" Never, "2" Rarely, "3" Sometimes, "4" Generally, "5" Always) and it is a gradation scale. The necessary validity and reliability analyses of the scale were performed. It was found 0.83 for the whole scale, 0.83 for internal self-confidence factor and 0.85 for external self-confidence factor. It was determined that test-retest reliability correlation coefficients of the scale were 0.94 for the whole scale, 0.97 for internal self-confidence and 0.87 for external self-confidence and item-total test correlations varied between 0.30 and 0.72 (Kandemir, 2015).

\section{FINDINGS}

Table 1. Self-Confidence Score Averages by the Variables in the Research

\begin{tabular}{|c|c|c|c|}
\hline Variable & $\begin{array}{c}\text { Self- } \\
\text { confidence }\end{array}$ & $\begin{array}{c}\text { Internal Self- } \\
\text { confidence }\end{array}$ & $\begin{array}{c}\text { External Self- } \\
\text { confidence }\end{array}$ \\
\hline Gender & 4,1895 & 4,2218 & 4,1551 \\
\hline University & 4,1895 & 4,2218 & 4,1551 \\
\hline Department & 4,1895 & 4,2218 & 4,1551 \\
\hline Class & 4,1895 & 4,2218 & 4,1551 \\
\hline Success in Sports State & 4,1895 & 4,2218 & 4,1551 \\
\hline Duration of Playing Sports & 4,1895 & 4,2218 & 4,1551 \\
\hline Age & 4,1895 & 4,2218 & 4,1551 \\
\hline
\end{tabular}


www.sstbdergisi.com

International Refereed Academic Journal of Sports, Health and Medical Sciences

January / February / March Winter Term Issue: 18 Year: 2016

GEL CODE: A14-C12-C38-C39-D23-M10-M19 ID:276 K:346

ISSN Print: 2146-8508 Online 2147-1711

(ISO 9001-2008 Document No: 12879 \& ISO 14001-2004 Document No: 12880)

(TRADEMARK)

(2015/04315- 2015-GE-18972)

According to Table 1, when score average of self-confidence levels and sub-dimension of genders is observed, it is seen that variables have high level self-confidence score averages.

Table 2. The Relation Between Importance of Success in Sports and Self-Confidence Levels

\begin{tabular}{|c|c|c|cc|c|}
\hline Score & \multicolumn{2}{|c|}{ Groups } & N & & P \\
\hline Importance of & A little important & 2 & 54,75 & & \\
Success in Sports & Important & 19 & 40,11 & 0,681 & 2 \\
& Very important & 62 & 42,17 & & 0,711 \\
\hline Total & & 83 & & & \\
\hline
\end{tabular}

According to Table 2, when the relation between perception of success in sports and self-confidence levels of the athletes are ob- served, there is not any significant difference in $\mathrm{P}<0,05$ level.

Table 3. Comparison of Self-Confidence Levels in Terms of Gender Variable

\begin{tabular}{|c|c|c|c|c|c|c|c|}
\hline $\begin{array}{c}\text { Self- } \\
\text { confidence }\end{array}$ & Gender & $\mathrm{N}$ & M & SS & SD & $\mathrm{T}$ & $\mathrm{P}$ \\
\hline $\begin{array}{c}\text { Self- } \\
\text { confidence } \\
\text { General }\end{array}$ & $\begin{array}{c}\text { Male } \\
\text { Female }\end{array}$ & $\begin{array}{l}42 \\
41\end{array}$ & $\begin{array}{l}4,0729 \\
4,3089\end{array}$ & $\begin{array}{l}, 30831 \\
, 32356\end{array}$ & 81 & $-3,403$ & 0,001 \\
\hline $\begin{array}{l}\text { Internal Self- } \\
\text { confidence }\end{array}$ & $\begin{array}{l}\text { Male } \\
\text { Female }\end{array}$ & $\begin{array}{l}42 \\
41\end{array}$ & $\begin{array}{l}4,1275 \\
4,3185\end{array}$ & $\begin{array}{l}, 37630 \\
, 33560\end{array}$ & 81 & $-2,439$ & 0,017 \\
\hline $\begin{array}{l}\text { External Self- } \\
\text { confidence }\end{array}$ & $\begin{array}{l}\text { Male } \\
\text { Female }\end{array}$ & $\begin{array}{l}42 \\
41\end{array}$ & $\begin{array}{l}4,0149 \\
4,2988\end{array}$ & $\begin{array}{l}, 36673 \\
, 41210\end{array}$ & 81 & $-3,317$ & 0,001 \\
\hline Total & & 83 & & & & & \\
\hline
\end{tabular}

According to Table 3, when self-confidence values and internal and external self-confi- dence values which are sub-dimensions of self-confidence are compared with each other 


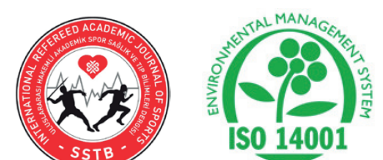

SSTB

www.sstbdergisi.com

International Refereed Academic Journal of Sports, Health and Medical Sciences

January / February / March Winter Term Issue: 18 Year: 2016

GEL CODE: A14-C12-C38-C39-D23-M10-M19 ID:276 K:346

ISSN Print: 2146-8508 Online 2147-1711

(ISO 9001-2008 Document No: 12879 \& ISO 14001-2004 Document No: 12880)

(TRADEMARK)

(2015/04315- 2015-GE-18972)

in terms of gender variable according to Independent samples $t$ test, there are significant differences in $\mathrm{p}<0,05$ level. Self-confidence levels of female participants were found to be higher than male participants.

Table 4. Comparison of Self-Confidence Levels in Terms of Department Variable

\begin{tabular}{|c|c|c|c|c|c|c|c|}
\hline $\begin{array}{l}\text { Self- } \\
\text { confidence }\end{array}$ & Gender & $\mathbf{N}$ & $\mathbf{M}$ & Ss & Sd & $\mathbf{T}$ & $\mathbf{P}$ \\
\hline $\begin{array}{l}\text { Self- } \\
\text { confidence } \\
\text { General }\end{array}$ & $\begin{array}{l}* \text { SPES } \\
\text { Other }\end{array}$ & $\begin{array}{l}59 \\
24\end{array}$ & $\begin{array}{l}4,2080 \\
4,1439\end{array}$ & $\begin{array}{l}, 34663 \\
, 30945\end{array}$ & 81 & 0,786 & 0,434 \\
\hline $\begin{array}{l}\text { Internal Self- } \\
\text { confidence }\end{array}$ & $\begin{array}{l}\text { SPES } \\
\text { Other }\end{array}$ & $\begin{array}{l}59 \\
24\end{array}$ & $\begin{array}{l}4,2080 \\
4,1520\end{array}$ & $\begin{array}{l}, 38520 \\
, 31602\end{array}$ & 81 & 1,107 & 0,272 \\
\hline $\begin{array}{l}\text { External Self- } \\
\text { confidence }\end{array}$ & $\begin{array}{l}\text { SPES } \\
\text { Other }\end{array}$ & $\begin{array}{l}59 \\
24\end{array}$ & $\begin{array}{l}4,1631 \\
4,1354\end{array}$ & $\begin{array}{l}\text {,40853 } \\
, 43170\end{array}$ & 81 & 0,276 & 0,783 \\
\hline Total & & 83 & & & & & \\
\hline
\end{tabular}

*SPES $=$ School of Physical Education and Sports

According to Table 4, when self-confidence values and internal and external self-confi- dence values which are sub-dimensions of self-confidence are compared with each other in terms of department variable according to Independent samples $t$ test, there are not significant differences in $\mathrm{p}<0,05$ level. 
www.sstbdergisi.com

International Refereed Academic Journal of Sports, Health and Medical Sciences

January / February / March Winter Term Issue: 18 Year: 2016

GEL CODE: A14-C12-C38-C39-D23-M10-M19 ID:276 K:346

ISSN Print: 2146-8508 Online 2147-1711

(ISO 9001-2008 Document No: 12879 \& ISO 14001-2004 Document No: 12880)

(TRADEMARK)

(2015/04315- 2015-GE-18972)

Table 5. Comparison of Self-Confidence Levels in Terms of Class Variable

\begin{tabular}{|c|c|c|c|c|c|c|}
\hline & & $\begin{array}{l}\text { Sum of } \\
\text { Squares }\end{array}$ & Sd & $\begin{array}{c}\text { Average of } \\
\text { Squares }\end{array}$ & $\mathbf{F}$ & $\mathbf{P}$ \\
\hline & Intergroup &, 360 & 3 & 0,120 & 1,066 & 0,368 \\
\hline \multirow{3}{*}{$\begin{array}{l}\text { Self- } \\
\text { confidence }\end{array}$} & Intragroup & 8,882 & 79 & 0,112 & & \\
\hline & Total & 9,241 & 82 & & & \\
\hline & Intergroup & ,780 & 3 & ,260 & 1,997 & 0,121 \\
\hline \multirow{2}{*}{$\begin{array}{l}\text { Internal Self- } \\
\text { confidence }\end{array}$} & Intragroup & 10,288 & 79 & , 130 & & \\
\hline & Total & 11,068 & 82 & & & \\
\hline \multirow{3}{*}{$\begin{array}{l}\text { External Self- } \\
\text { confidence }\end{array}$} & Intergroup & ,243 & 3 & ,081 & 0,465 & 0,707 \\
\hline & Intragroup & 13,737 & 79 & , 174 & & \\
\hline & Total & 13,979 & 82 & & & \\
\hline
\end{tabular}

According to Table 5, when self-confidence in terms of class variable according to Indevalues and internal and external self-confidence values which are sub-dimensions of pendent samples $t$ test, there are not signifiself-confidence are compared with each other cant differences in $p<0,05$ level. 


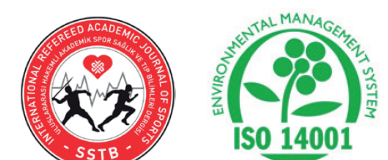

SSTB

www.sstbdergisi.com

International Refereed Academic Journal of Sports, Health and Medical Sciences

January / February / March Winter Term Issue: 18 Year: 2016

GEL CODE: A14-C12-C38-C39-D23-M10-M19 ID:276 K:346

ISSN Print: 2146-8508 Online 2147-1711

(ISO 9001-2008 Document No: 12879 \& ISO 14001-2004 Document No: 12880)

(TRADEMARK)

(2015/04315- 2015-GE-18972)

Table 6. Comparison of Self-Confidence Levels in Terms of Duration of Playing Sports Variable

\begin{tabular}{|c|c|c|c|c|c|c|}
\hline & & $\begin{array}{l}\text { Sum of } \\
\text { Squares }\end{array}$ & Sd & $\begin{array}{c}\text { Average of } \\
\text { Squares }\end{array}$ & $\mathbf{F}$ & $\mathbf{P}$ \\
\hline & Intergroup & 1,298 & 15 & ,087 &, 730 & 0,746 \\
\hline \multirow{3}{*}{$\begin{array}{l}\text { Self- } \\
\text { confidence }\end{array}$} & Intragroup & 7,943 & 67 & ,119 & & \\
\hline & Total & 9,241 & 82 & & & \\
\hline & Intergroup & 1,867 & 15 &, 124 & ,906 & 0,561 \\
\hline \multirow{2}{*}{$\begin{array}{l}\text { Internal Self- } \\
\text { confidence }\end{array}$} & Intragroup & 9,201 & 67 & ,137 & & \\
\hline & Total & 11,068 & 82 & & & \\
\hline \multirow{3}{*}{$\begin{array}{l}\text { External } \\
\text { Self- } \\
\text { confidence }\end{array}$} & Intergroup & 2,151 & 15 &, 143 & ,812 & 0,661 \\
\hline & Intragroup & 11,829 & 67 & , 177 & & \\
\hline & Total & 13,979 & 82 & & & \\
\hline
\end{tabular}

According to Table 6, when the relation besub-dimensions are observed, there is not any tween duration of playing sports and self- significant difference $(p<0,05)$. confidence levels of the athletes and their 
www.sstbdergisi.com

International Refereed Academic Journal of Sports, Health and Medical Sciences

January / February / March Winter Term Issue: 18 Year: 2016

GEL CODE: A14-C12-C38-C39-D23-M10-M19 ID:276 K:346

ISSN Print: 2146-8508 Online 2147-1711

(ISO 9001-2008 Document No: 12879 \& ISO 14001-2004 Document No: 12880)

(TRADEMARK)

(2015/04315- 2015-GE-18972)

Table 7. Evaluation of Self-Confidence Levels of the Athletes Attending the Research by Their Ages

\begin{tabular}{|c|c|c|c|c|c|c|}
\hline & & $\begin{array}{l}\text { Sum of } \\
\text { Squares }\end{array}$ & Sd & $\begin{array}{c}\text { Average of } \\
\text { Squares }\end{array}$ & $\mathbf{F}$ & $\mathbf{P}$ \\
\hline & Intergroup & ,018 & 2 & ,009 & ,077 & 0,926 \\
\hline \multirow[t]{3}{*}{ Self-confidence } & Intragroup & 9,224 & 80 & ,115 & & \\
\hline & Total & 9,241 & 82 & & & \\
\hline & Intergroup & ,149 & 2 &, 074 &, 545 & 0,582 \\
\hline \multirow{2}{*}{$\begin{array}{l}\text { Internal Self- } \\
\text { confidence }\end{array}$} & Intragroup & 10,919 & 80 & , 136 & & \\
\hline & Total & 11,068 & 82 & & & \\
\hline \multirow{2}{*}{$\begin{array}{l}\text { External Self- } \\
\text { confidence }\end{array}$} & Intergroup &, 243 & 2 & ,019 & , 109 & ,896 \\
\hline & Intragroup & 13,737 & 80 &, 174 & & \\
\hline & Total & 13,979 & 82 & & & \\
\hline
\end{tabular}

According to Table 7, when the relation between ages of the athletes attending the research and their self-confidence levels and sub-dimensions are observed, there is not any significant difference $(\mathrm{p}>0,05)$. 


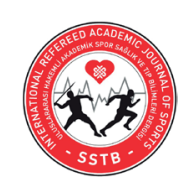

SSTB

www.sstbdergisi.com

International Refereed Academic Journal of Sports, Health and Medical Sciences

January / February / March Winter Term Issue: 18 Year: 2016

GEL CODE: A14-C12-C38-C39-D23-M10-M19 ID:276 K:346

ISSN Print: 2146-8508 Online 2147-1711

(ISO 9001-2008 Document No: 12879 \& ISO 14001-2004 Document No: 12880)

(TRADEMARK)

(2015/04315- 2015-GE-18972)

Table 8. Evaluation of Self-Confidence Levels of the Athletes

Attending the Research by Their Universities

\begin{tabular}{|l|c|c|c|c|c|c|}
\hline & & $\begin{array}{c}\text { Sum of } \\
\text { Squares }\end{array}$ & Sd & $\begin{array}{c}\text { Average of } \\
\text { Squares }\end{array}$ & F & P \\
\hline & Intergroup & 1,298 & 15 &, 087 &, 730 & 0,746 \\
\hline Self-confidence & Intragroup & 7,943 & 67 &, 119 & & \\
\hline & Total & 9,241 & 82 & & & \\
\hline $\begin{array}{l}\text { Internal Self- } \\
\text { confidence }\end{array}$ & Intergroup & 1,867 & 15 &, 124 &, 906 & 0,561 \\
& Intragroup & 9,201 & 67 &, 137 & & \\
\hline \multirow{2}{*}{$\begin{array}{l}\text { External Self- } \\
\text { confidence }\end{array}$} & Total & 11,068 & 82 & & & \\
& Intergroup & 2,151 & 15 &, 143 &, 812 &, 661 \\
\hline & Intragroup & 11,829 & 67 &, 177 & & \\
\hline
\end{tabular}

According to Table 8, when the relation between universities of the athletes attending the research and their self-confidence levels and sub-dimensions are observed, there is not any significant difference $(\mathrm{p}>0,05)$.

\section{DISCUSSION and CONCLUSION}

When the results of the study were examined, the relation of various variables with selfconfidence perception levels for the athletes playing tennis in terms of self-confidence perceptions were observed and it was seen that the athletes had significant difference only in the variable of gender $(p<0,05)$. Furthermore, significant differences were also found between internal and external self-confidence states which were sub-dimensions of self-confidence within the gender variable.

In the comparison made within the scope of the study in terms of gender variable and self-confidence perception states and sub-dimensions, it was seen that female athletes had higher self-confidence levels than male athletes. In another study titled "The Relationship of Playing Sports and Self-Confidence in High School Students" which was conducted by Arslan et al., (2015) regarding self-confidence, there was not any significant difference in terms of gender variable and self-con- 


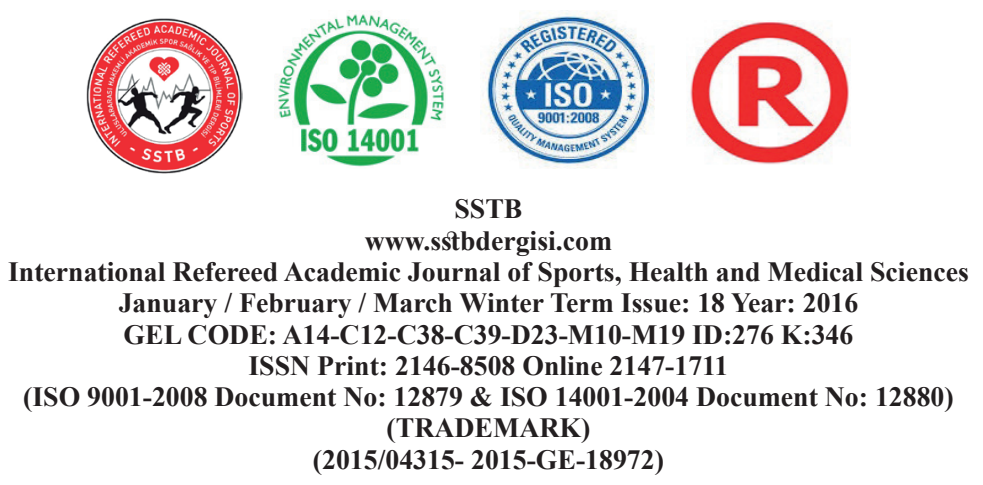

fidence perception state $(p>0,05)$. Moreover, self-confidence perception score averages of male participants were found to be higher than female participants. This result does not show parallelism with the result of our study. When the answers given to importance of success in sports which was among the demographic variables asked to the athletes in our study were examined, there was not any significant difference among genders and departments. It could not established a relationship between expectation of success taking place in the nature of sports and the perception of self-confidence in sports depending on the given answers; however it can be stated that athletes should believe in themselves, be aware of their skills and believe that they can be successful (Yeltepe, 2007).

In the study conducted by Feltz (1988) regarding success in sports, it is specified that the athlete can increase her/his performance in sports with self-confidence and competencies in spite of the complex nature of sports and changes in the conditions for being successful. When the relation between class which was another variable of the study and selfconfidence perception levels was observed, it was not found any significant differences between class variable and self-confidence perception levels and its sub-dimensions $(\mathrm{p}>0,05)$. In the study conducted by Arslan et al., (20159, significant differences were found between internal self-confidence perception level and class variable and statistical findings were found among class variables; therefore we can say that it differs from our study with this aspect. However, when external self-confidence levels are observed, it is seen that it is in the same direction with our study $(p>0,05)$. When the relation between Department and Self-confidence Perception levels were observed in the study, there was not any significant differences among departments in terms of self-confidence perception levels $(p>0,05)$. However, it does not show parallelism with another study (Kandemir, 2015) titled "Self-Confidence Perceptions of Faculty of Science and Letters Geography Department Students" comprising the studied program variable and self-confidence level. There is a significant difference between department variable and self-confidence perception levels in the study $(\mathrm{p}<0,05)$.

There is not any difference between variables such as university, age, duration of playing sports and importance of success in sports for the athlete, which are other variables of the study and self-confidence perception.

\section{REFERENCES}

AKIN, A., (2007). Öz-Güven Ölçeği'nin Geliştirilmesi ve Psikometrik Özellikleri. AİBU, Eğitim Fakültesi Dergisi, Volume 7, No 2, 165-175 


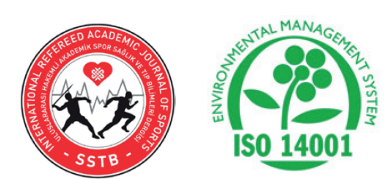

SSTB

www.sstbdergisi.com

International Refereed Academic Journal of Sports, Health and Medical Sciences

January / February / March Winter Term Issue: 18 Year: 2016

GEL CODE: A14-C12-C38-C39-D23-M10-M19 ID:276 K:346

ISSN Print: 2146-8508 Online 2147-1711

(ISO 9001-2008 Document No: 12879 \& ISO 14001-2004 Document No: 12880)

(TRADEMARK)

(2015/04315- 2015-GE-18972)

ARSLAN et al., (2015). Lise Öğrencilerinde Spor Yapma Ve Özgüven İlişkisi. International Refereed Academic Journal of Sports, October / November / December - Fall-Winter Term No: 17

BANDURA, A., and ADAMS, N.,E., (1977). Analysis Of Self-Efficacy Theory Of Behavioral Change. Cognitive Therapy and Research, Vol 1, No 4, Pp 287-310

DALKILIÇ, M., (2011). İlköğretim Öğrencilerinin Sportif Faaliyetlere Katılım Düzeyi ve İletişim Becerileri Arasındaki İlişkilerin İncelenmesi. T.R. Karamanoğlu Mehmet Bey University Institute of Social Sciences. Master's Thesis

DOG $\breve{A} \boldsymbol{N}, \boldsymbol{O}$., (2005). Spor Psikolojisi. Nobel Kitapevi, Second Edition, Adana

FELTZ, L.D., (1988). Self-Confidence And Sports Performance. Exercise and Sport Science Reviews 16: 423-457

FIŞEK, K., (1998). Türkiye'de ve Dünya'da Spor Yönetimi. Bağırgan Yayınevi, Ankara
KANDEMIR, K., (2015). Fen Edebiyat Fakültesi Coğrafya Bölümü Öğrencilerinin Özgüven Algiları. KSU Sosyal Bilimler Dergisi Vol:12 No:1

KONTER, E., (1998). Sporda Psikolojik Hazırlığın Teori ve Pratiği. Bağırgan Yayımevi, Kızılay/ Ankara

VAELEY, R.S., (1986). Self-Confidence: SportSpecific Self-Confidence. https://sportspsych. wikispaces.com/file/view/Sport+specific+selfconfidence+overview.pdf (11.09.2015)

VAELEY, R.,S., HAYASHI, S.,W., GARNERHOLMAN, M., and GİACOBBİ, P., (1998). Sources Of Sport-Confidence: Conceptualization and Instrument Development. Journal Of Sport \& Exercise Psychology 20 (1), 54-80

YELTEPE, H., (2007). Spor ve Egzersiz Psikolojisi. Epsilon Yayıncılık Hizmetleri Tic. San. Ltd. Şti. Kağıthane/İstanbul 